\title{
The Study to Improve College Students' Ability of Innovation by Art Education
}

\author{
Bi-yun LIN
}

\begin{abstract}
Bi-yun LIN, Tianjin College, University of Science and Technology Beijing, 15022129062, cxy031058@126.com
\end{abstract}

\section{Keywords: Universities, Art Education, innovation.}

\begin{abstract}
Art education have diversified values and functions, which can stimulate college students' innovative thinking and improve their innovative ability. It is an important part of cultivating high-quality innovative talent education. So we should continuously improve and consummate the methods and measures of art education in colleges and universities through multidisciplinary integration, we need strengthen the innovation ability of college students by optimizing the curriculum structure, reforming the talent training mode, updating the educational ideas, attaching importance to individual differences, and constructing the subject art education mode. Cultivation.
\end{abstract}

\section{Introduction}

"Accelerating the pace of creating world-class universities and high-level universities, and cultivating a group of top-notch innovative talents" is a strategic task of China's university development in the <National Medium and Long Term Education Reform and Development Plan>(2010-2020. It is an important task for Chinese universities to cultivating talents with creative thinking and innovative ability. Nowadays, all the colleges and universities in China are actively exploring the theory and practice of innovative talent training. However, cultivating and cultivating innovative talents is not a task that intellectual education can accomplish alone. To achieve this goal, it is necessary to use disciplines.

Some studies have shown that the art education have unreplaceable advantages in stimulating the creative potential, cultivating innovative ability and shaping innovative personality to college students. Many western countries have already begun to explore this aspect as early as the last century. In 1990, the American Association for the Advancement of Science (AAAS) published a report entitled "The Art of Freedom of Science", arguing that "the science education needs fundamental reform, and must be combined with art education." Harvard University implements the"Core Curriculum" program, which stipulates that in addition to studying majors, the undergraduates must also study courses in other disciplines, especially art disciplines; MIT also requires students to study music and art in addition to engineering and engineering disciplines. The foreign advanced teaching concepts are worth learning from.

\section{The connection between art education and innovative talents training}

As an activity of human creation culture, art's eternal goal is innovation. The art is developed in the continuous inheritance and innovation of mankind. Therefore, the artistic is originally an innovation. For art education, the cultivation of innovative spirit is an essential element that is unavoidable. So we can think that the combination of science and art is an important way to cultivate innovative talents. The art education always play an important role in cultivating students' innovative thinking. According to the art education, college students own enriched Imagination and creative thinking ability, it promotes their innovative thinking in the future. 


\section{The main problems in the cultivation of college students' innovative ability}

\subsection{Ignore the emotional education.}

At present, many colleges and universities generally attach more importance to the cognitive education of college students, but they do not pay enough attention to emotional education. They neglect the most abundant and energetic emotional factors, and and turn the educational process into a boring developmental intellectual process.

\subsection{The professional curriculum is too detailed and it restricts the students' innovate ability.}

The professional curriculum of colleges and universities is too detailed, and the tasks of the curriculum are heavy. Most College students just did a good job of learning, and neglect the study of other disciplines and majors, resulting in narrow vision and limited innovation ability.

\subsection{Colleges and universities only attach importance to knowledge but not the ability training.}

For a long time, China's higher education has been influenced by the ideas of "teaching center, teacher center and classroom center" , the teaching method is still based on "instillation". In the classroom, the teacher's lecture is the center, the students become passive receptors, the method is dull, and there is no new idea. Under this teaching mode, college students mainly rely on the understanding and memory of knowledge, lack of ability to cultivate, resulting in the students' emphasis on knowledge, light ability, emphasis on theory and light practice in the practice of education. The initiative of students is not high.

\section{Ways to Strengthen the Cultivation of College Students' Innovative Ability through Art Education}

\subsection{Renewing the education concept and stimulating the innovative thinking fully by art education.}

The innovative thinking is a comprehensive and powerful way of thinking.It consists of opposite divergent thinking and convergent thinking, and is the core of innovation ability. Art education needs to constantly train students to divergent thinking ability, intuitive thinking ability, image thinking ability, type recognition ability and imagination. While taking image thinking as the leading factor, accompanied by the development of logical thinking, it can maximize the Improve the physiology of the brain. In the teaching, students are required to have nuanced observation, creative thinking, good memory, rich imagination, decisive and accurate judgment, and agile resilience. These abilities are the good methods toexpanding students' thinking space and developing right brain potential.

\subsection{Optimizing the curriculum structure, and promoting the development of art education in}

\section{colleges and universities.}

The curriculum structure construction should be maximized and be included in the planning of college education. The combination of science and art is the mainstream of future human thought development. The art is becoming more and more scientific, and the science is becoming more and more artistic. It is the inevitable result of history. The art education in colleges and universities involve various fields and levels of humanities and society, and develop into cross-disciplinary disciplines. So in the process of art education, we should give full play to the advantages of multidisciplinary integration in universities. In addition to the regular art courses, art discipline teachers can also jointly offer courses in digital music, computer art, and digital art design with computer science teachers, so that the art education in colleges and universities will continue to develop. At the same time, teachers can try to use art as an introduction, skillfully connecting art and science, and cultivating innovative ways of thinking for college students. In the teaching process, the music can be introduced to the students to introduce the local people's living customs, costumes, living environment, religious beliefs and national culture, and to link music education 
with literature, geography, history and other knowledge.

\subsection{Reforming the training talents mode, and strengthening the cultivation of college students' innovative consciousness with art education.}

The innovative awareness is the driving force for people to engage in innovative activities, and it is the premise of innovative thinking and innovative behavior. To cultivate the innovative ability of college students, we must first cultivate the innovative consciousness of college students. Art education has a profound and long-lasting influence on the human spiritual world in a subtle way. Because of its positive and potential impact on human imagination and creativity, It is difficult to replace by other education. In art education, we must abandon the talent cultivation model of "full house irrigation" and create a harmonious and democratic learning atmosphere for students. When we are teaching students to play music, they can try to guide students to understand the music, to explore the role, to understand the style of different music, to develop imagination, to express their inner feelings in music language, and to express emotions with music. In this way, the music performance class has became a space for students to show their talents. Students can not only perform the performance of the music well, but also reflect their unique feelings and tastes. Because the students' mind and body are in a state of liberation, the sense of innovation is fully mobilized, and the ability to innovate is naturally cultivated.

\subsection{Constructing a subjective art education model and strengthening innovation practice.}

Constructing a subjective art education model, taking students as the main body of art education and innovative learning, respecting their innovative spirit and strengthening innovative practice is the best form of art education.The development of any kind of skill must pay hard work and sweat. The art education process is an effective way to train willpower and improve the ability. Students can be encouraged to participate in art practice activities in person, so that the ability of image expression can be effectively developed through certain creative practices. In the practice, students are no longer passive recipients but subjects, which inspires them to envision something that does not exist in reality, motivate them to achieve these ideas, and practice and ultimately be reflected. In art education, many art forms such as chorus, ensemble, drama, dance, art design, etc., require participants to cooperate with the collective and work together to produce good results. In these artistic practice, college students can understand themselves better and find the true value of themselves. Their cooperative attitude and coordination ability can gain emotional experience and effective training. As far as art education is concerned, practice is the process of perception, imagination, and inspiration. It is also the process of thinking, discovering, and cooperating. Therefore, colleges and universities should formulate practical and feasible teaching plans according to their own facilities, conditions and teachers, actively provide art practice classes for college students, and provide opportunities for college students to innovate.

\section{The conclusion}

The art education has played a great role in the cultivation of innovative talents in colleges and universities. Strengthening innovation and breakthroughs in the field of art education and scientific research, following the rules of art education, exploring ways of art education, cultivating students' sense of innovation, and cultivating national innovative talents are important issues facing colleges and universities in the future. Art education is an important part of the education in China. It is inextricably linked with the cultivation of high-quality innovative talents. Without art education,the education is incomplete and the higher education requires art education. The level of art education has become one of the criteria for measuring the quality of education in a country. Colleges and universities should become the model for the reform and development of art education, and cultivate high-quality innovative talents for China's economic construction and social development. 


\section{Acknowledgement}

This work was supported by TianJin social science foundation(TJTQQN17-001)

\section{References}

[1] Shao Luzhen. Research on the Position Expansion of College Students' Innovation and Entrepreneurship Education-Taking the Public Art Courses of Colleges and Universities as the Entry Point[J]. China University Student Employment, 2016(08): 34-38.

[2] Liu Weilan, Yuan Li. Development and Innovation: A Review of the Australian National Art Curriculum Outline of New Art Education [J]. Foreign Elementary and Secondary Education, 2016(01): 52-56.

[3] Wang Lilin, Zhang Ruizhi. Inheriting Innovation, Giving Full Play to the Role of Art Education in Talent Cultivation[J]. University Teaching in China, 2015(05): 30-32.

[4] YANG Chunhua, SHEN Xiaowen. Analysis on the Difficulties and Ways of Public Art Education Reform in Higher Vocational Colleges[J]. China Vocational and Technical Education, 2014(31): 89-92.

[5] Zou Linlin. On the Ways of Developing Art Education and Its Role in the Construction of University Culture[J]. Higher Agricultural Education, 2014(09): 28-31.

[6] Wang Shoulun. Innovative Art Education Mechanism to Improve Students' Artistic Quality[J]. China Higher Education, 2013(07): 37-38.

[7] Chen Xiaoyan. Practice and Innovation of College Public Art Education under the Concept of General Education[J].Jiangsu Higher Education,2010(04):70-71.

[8] Wang Dongxing, $\mathrm{Xu}$ Guoshuai. The Role of Art Education in Cultivating the Creativity of Innovative Talents[J]. Journal of Hebei Normal University (Educational Science Edition), 2010, 12(04): 121-123. 